MR. ANTONIO CASTELLANO-HINOJOSA (Orcid ID : 0000-0002-5785-7625)

DR. FABRICIO CASSÁN (Orcid ID : 0000-0002-9776-0262)

Article type : Original Article

\title{
Analysis of the denitrification pathway and greenhouse gases emissions in Bradyrhizobium sp. strains used as biofertilizers in South America
}

\section{GEI emissions from Bradyrhizobium sp.}

Obando, Melissa ${ }^{\mathrm{a}}$, Correa-Galeote, David ${ }^{\mathrm{b}}$, Castellano-Hinojosa, Antonio ${ }^{\mathrm{b}}$, Gualpa, José $^{\mathrm{a}}$, Hidalgo, Alba ${ }^{\mathrm{b}}$, Alché, Juan de Dios ${ }^{\mathrm{c}}$, Bedmar, Eulogio ${ }^{\mathrm{b} *}$, Cassán, Fabricio ${ }^{\mathrm{a}^{*}}$

*BEJ and CF contributed equally to this work

${ }^{a}$ Laboratorio de Fisiología Vegetal e Interacción Planta-Microorganismo, Universidad Nacional de Río Cuarto. Ruta 36, Km 601, Río Cuarto, Córdoba, Argentina.

${ }^{\mathrm{b}}$ Departamento de Microbiología del Suelo y Sistemas Simbióticos, Estación Experimental del Zaidín-CSIC. E-18008 Granada, Spain.

${ }^{c}$ Departamento de protección Vegetal. Estación Experimental del Zaidín-CSIC. E-18008 Granada, Spain.

* Corresponding author. Tel.: +54 9358 4127370; fax: +54 03584676230.

E-mail address: fcassan@exa.unrc.edu.ar (F. Cassan)

This article has been accepted for publication and undergone full peer review but has not been through the copyediting, typesetting, pagination and proofreading process, which may lead to differences between this version and the Version of Record. Please cite this article as doi: $10.1111 /$ jam. 14233

This article is protected by copyright. All rights reserved. 


\section{Abstract}

Aims: Greenhouse gases are considered potential atmospheric pollutants, with agriculture being one of the main emission sources. The practice of inoculating soybean seeds with Bradyrhizobium sp. might contribute to nitrous oxide $\left(\mathrm{N}_{2} \mathrm{O}\right)$ emissions. We analyzed this capacity in five of the most used strains of Bradyrhizobium sp. in South America.

Methods and Results: We analyzed the denitrification pathway and $\mathrm{N}_{2} \mathrm{O}$ production by $B$. japonicum E109 and CPAC15, B. diazoefficiens CPAC7, and B. elkanii SEMIA 587 and SEMIA 5019, both in free-living conditions and symbiosis with soybean. The in silico analysis indicated the absence of nos $Z$ genes in B. japonicum and the presence of all denitrification genes in B. diazoefficiens strains, as well as the absence of nir $\mathrm{K}$, nor $\mathrm{C}$ and nos $\mathrm{Z}$ genes in B. elkanii. The in planta analysis confirmed the $\mathrm{N}_{2} \mathrm{O}$ production under saprophytic conditions or symbiosis with soybean roots nodules. In the last case up to 26.1 and 18.4 times higher in plants inoculated with SEMIA5019 and E109 respectively, than in those inoculated with USDA110.

Conclusions: The strains E109, SEMIA 5019, CPAC15 and SEMIA 587 showed the highest $\mathrm{N}_{2} \mathrm{O}$ production both as free-living cells and in symbiotic conditions in comparison with USDA110 and CPAC7, which do have the nosZ gene. Although norC and nosZ could not be identified in silico or in vitro in SEMIA 587 and SEMIA 5019, these strains showed capacity to produce $\mathrm{N}_{2} \mathrm{O}$ in our experimental conditions.

Significance and Impact of Study: This is the first report to analyze and confirm the incomplete denitrification capacity and $\mathrm{N}_{2} \mathrm{O}$ production in four of the five most used strains of Bradyrhizobium sp. for soybean inoculation in South America.

Keywords: greenhouse gases; denitrification; soybean; Bradyrhizobium; biofertilizers. 


\section{Introduction}

Denitrification is an alternative respiration pathway in which microorganisms under oxygenlimiting conditions reduces nitrate $\left(\mathrm{NO}_{3}^{-}\right)$to nitrite $\left(\mathrm{NO}_{2}^{-}\right)$through nitrate reductase enzymes encoded by the narG/napA genes. Nitrite reductase enzymes encoded by the nirS/nirK genes then reduce $\mathrm{NO}_{2}^{-}$to nitric oxide (NO) and nitric oxide reductase encoded by the norB/norC genes reduce $\mathrm{NO}$ to nitrous oxide $\left(\mathrm{N}_{2} \mathrm{O}\right)$. Finally, $\mathrm{N}_{2} \mathrm{O}$ is reduced by nitrous oxide reductase, which is encoded by the nos $Z$ gene. This leads to the formation of molecular nitrogen $\left(\mathrm{N}_{2}\right)$ as an end product (Bueno et al. 2012). However, not all denitrifying organisms have the genetic capacity for $\mathrm{NO}$ and $\mathrm{N}_{2} \mathrm{O}$ reduction, and this causes the release of $\mathrm{N}$-gases involved in global climate change (Hallin et al. 2012). Legumes, a large group of plants capable of growing under different edaphic and climatic conditions, form a broad family named Fabaceae (Leguminosae) that comprises around 20,000 species and 750 genera with representatives in nearly every terrestrial

biome on Earth (Lewis et al. 2005; Peix et al. 2015). Together with actinorhizal plants, legumes are unique among higher plants because of their ability to establish $\mathrm{N}_{2}$-fixing symbiotic associations with soil bacteria, collectively referred to as rhizobia. Soybean (Glycine $\max$ L.) is a crop legume grown all over the world, and Brazil and Argentina are the second and third largest soybean producers worldwide (Meade et al. 2016). In 2017, both countries were responsible for around $47 \%$ of the total global soybean production, with a planted area in the 2016/2017 season of 33.9 and 19.6 million hectares, respectively (United States Department of Agriculture, 2017); However, a gradual increase in these figures is expected in future seasons (Bolsa de Cereales de Buenos Aires, 2018). Soybean establishes symbiotic $\mathrm{N}_{2}$-fixing associations with members of the family Nitrobacteriaceae (Bradyrhizobiaceae), which belongs to the Rhizobial order of Alphaproteobacteria. These associations occur mainly with species of the genus Bradyrhizobium, although Ensifer and 
Mesorhizobium have also been shown to be microsymbionts of Glycine (Shamseldin et al. 2017). Many legume-nodulating rhizobacteria do not perform complete denitrification. So far, only B. diazoefficiens (formerly B. japonicum) has been shown to contain and to express the complete set of denitrification genes leading to the reduction of nitrate to $\mathrm{N}_{2}$ (Bedmar $e t$ al. 2005; Bueno et al. 2012). Inoculation of soybean has been a common, extensive agricultural practice in South America for over 40 years, mainly in Argentina and Brazil. Along with the cultivation of soybean, Bradyrhizobium species were introduced into the soil (Campos et al. 2001). Currently, the most commonly found strains used for inoculants production and use in South America are B. japonicum E109 and CPAC15 (formerly SEMIA 5079), B. diazoefficiens CPAC7 (formerly SEMIA 5080) and B. elkanii SEMIA 587 and SEMIA 5019. While our research was underway, the sequenced genomes of strains E109 (Torres et al. 2015), CPAC 15 and CPAC 7 (Siqueira et al. 2014) were published. Therefore, there is now available knowledge on the presence or the absence of the denitrification genes in those strains at the in silico level. On the other hand, the genomes of strains SEMIA 587 and SEMIA 5019 have not been reported, and their denitrifying activity is unknown.

In previous reports, out of 250 strains of Bradyrhizobium sp. isolated from the nodules of soybean grown in Argentina, only 41 reduced nitrate to $\mathrm{N}_{2}$ (Fernández et al. 2008). Considering the vast extension of soil cultivated with soybean in this country, together with Brazil, and that nitrate is usually added during its growth, the cultivation of soybean is one of the main sources for $\mathrm{N}_{2} \mathrm{O}$ released into the atmosphere. Our research aimed to determine the denitrification capacity and $\mathrm{N}_{2} \mathrm{O}$ production in B. japonicum strains $\mathrm{E} 109$ and CPAC15, $B$. diazoefficiens strain CPAC7, and B. elkanii strains SEMIA 587 and SEMIA 5019, the most used strains for soybean inoculation in South America, both under free-living and symbiotic conditions.

This article is protected by copyright. All rights reserved. 


\section{Materials and methods}

Bacterial strains and growth conditions

B. elkanii SEMIA 587, SEMIA 5019; B. japonicum CPAC15 and E109 and B. diazoefficiens CPAC7 used in this study were provided by the Instituto de Microbiología y Zoología Agrícola, INTA-IMyZA, Castelar, Buenos Aires, Argentina. We also used B. diazoefficiens USDA 110 (formerly B. japonicum USDA) and its mutant derivatives GRC 131, lacking the norC gene (Mesa et al. 2002), and GRZ 3035, lacking the nosZ gene (Velasco et al. 2004). Bacteria were routinely grown in peptone salts yeast extract (PSY) medium (Regensburger and Hennecke, 1983$)$ supplemented with arabinose $\left(0.1 \%\right.$ w/v) for $5 \mathrm{~d}$ at $30^{\circ} \mathrm{C}$. Growth under microaerophilic conditions was performed in $17 \mathrm{ml}$ tubes containing $5 \mathrm{ml}$ Bergersen's minimal medium (Bergersen, 1977) supplemented with $10 \mathrm{mM} \mathrm{KNO}_{3}$, independently inoculated with $1 \mathrm{ml}\left(\sim 10^{8} \mathrm{CFU} \cdot \mathrm{ml}^{-1}\right)$ of a suspension of each strain and sealed with rubber septa stoppers. Then, the headspace atmosphere of the tubes was replaced by a gas mixture ( 2 $\%$ oxygen, $98 \%$ argon) before the cultures were incubated at $30{ }^{\circ} \mathrm{C}$. The gas was replaced every $12 \mathrm{~h}$ by flushing the tubes with the same gas mixture. The culture medium composition was adapted for the individual strains by addition of the following antibiotics $\left(\mu \mathrm{g} \cdot \mathrm{ml}^{-1}\right)$ : chloramphenicol 20 (USDA110); spectinomycin 200 (GRC131); streptomycin 100 (GRZ3035) and tetracycline 100 (GRZ3035).

\section{DNA extraction and PCR amplifications for SEMIA 587 and SEMIA 5019}

Genomic DNA was isolated from bacterial cells using the Real Pure Genomic DNA Extraction kit (Durviz, Spain), following the manufacturer's instructions. The quantity of DNA was determined using a Nanodrop spectrophotometer (NanoDrop ND1000, Thermo Fisher Scientific, USA). The denitrification genes napA, nirK, norB and nosZ were amplified using the specific primers described by Fernández et al. (2008) for Bradyrhizobium. The 
reaction conditions were the same for all genes analyzed in all the interest strains. Briefly, the reaction mixture contained: genomic DNA (80-100 ng), $2 \mathrm{mM}$ of each $\mathrm{dNTP}, 15 \mathrm{pmol}$ of each oligonucleotide primer, $1 \mathrm{U}$ of Taq DNA polymerase (Promega, WI) and $6 \%$ of DMSO. PCR was performed under the following conditions: (1) initial denaturation at $95^{\circ} \mathrm{C}$ for $5 \mathrm{~min}$; (2) 5 cycles at $95{ }^{\circ} \mathrm{C}$ for $1 \mathrm{~min}$, starting with an annealing temperature of $58{ }^{\circ} \mathrm{C}$ for 1 min, which decreased by $1{ }^{\circ} \mathrm{C}$ every cycle, $72{ }^{\circ} \mathrm{C}$ for $2 \mathrm{~min}$; (3) 30 cycles of denaturation at $95^{\circ} \mathrm{C}$ for $1 \mathrm{~min}$, primer annealing at $53{ }^{\circ} \mathrm{C}$ for $1 \mathrm{~min}$, and primer extension at $72^{\circ} \mathrm{C}$ for $2 \mathrm{~min}$; (4) a final extension at $72{ }^{\circ} \mathrm{C}$ for $10 \mathrm{~min}$.

\section{Denitrification activity and $\mathrm{N}_{2} \mathrm{O}$ detection in free-living cells}

To determine methyl viologen (MV)-dependent nitrate and nitrite reductase activities, aliquots of microaerophilic bacterial cultures, from 0.2 to $0.4 \mathrm{mg}$ of protein, were added to a reaction mixture (Sánchez et al. 2010). Reactions were started with the addition of sodium dithionite, run at $30{ }^{\circ} \mathrm{C}$ for $15 \mathrm{~min}$ and stopped through the oxidation of sodium dithionite by vortexing. Controls were run in parallel, but in these reactions sodium dithionite was oxidized at the start. Nitrite was estimated after diazotation by adding the sulfanilamide/naphthylethylene diamine dyhydrochloride reagent (Nicholas and Nason 1954). To determine nitric oxide reductase activity, a kinetic MV-dependent assay was used (Sánchez et al. 2010). Essentially, for each assay, a $3 \mathrm{ml}$ cuvette was filled with $2.5 \mathrm{ml}$ of 10 $\mathrm{mM}$ phosphate buffer (pH 7.5), $100 \mu$ l of cell solution (0.2-0.4 mg protein), and $25 \mu \mathrm{l}$ of 100 mM MV solution, then sealed with a mini suba-seal and made anaerobic by sparging with oxygen-free nitrogen gas for $10 \mathrm{~min}$. A $100 \mathrm{mM}$ sodium dithionite solution was freshly made and sparged before its addition with a gas-tight Hamilton syringe to the cuvette. Enough sodium dithionite was added to turn the solution blue, with an absorbance of approximately 2 at $600 \mathrm{~nm}$ in the spectrophotometer (DW-2000 [SLM-Aminco Instruments Inc., Rochester, N 
Y, U.S.A.] or U-3310 [Hitachi High-Technologies, Tokyo]). Once a steady base line was observed, $100 \mu \mathrm{l}$ of a saturated NO solution was added to the cuvette to begin the reaction. Each assay was run until the absorbance had dropped to zero, i.e. when all MV was oxidized. To assay nitrous oxide accumulation, cells were grown in Bergersen minimal medium under microoxic conditions with nitrate for $7 \mathrm{~d}$. Gas samples $(100 \mu \mathrm{l})$ were withdrawn every $12 \mathrm{~h}$ from the headspace with gas-tight syringes and injected into a gas chromatograph (HewletPackard HP 4890D) equipped with an electron capture detector and a Porapak Q 80/100 mesh (8 ft) packed column. $\mathrm{N}_{2}$ was the carrier gas at $30 \mathrm{ml} / \mathrm{min}$ flow rate and the injector, column and detector temperatures were $125^{\circ} \mathrm{C}, 60{ }^{\circ} \mathrm{C}$ and $375^{\circ} \mathrm{C}$, respectively. $\mathrm{N}_{2} \mathrm{O}$ concentrations were calculated using $2 \%$ (v/v) $\mathrm{N}_{2} \mathrm{O}$ standard (Air Liquid). The $\mathrm{N}_{2} \mathrm{O}$ production in liquid cultures was corrected using the $\mathrm{N}_{2} \mathrm{O}$ Bunsen solubility coefficient $\left(47.2 \%\right.$ at $\left.30^{\circ} \mathrm{C}\right)$.

\section{Protein determination}

The protein concentration of cell suspensions was estimated by using the Bio-Rad assay, with a standard curve of varying bovine serum albumin (BSA) concentrations.

\section{Inoculation of soybean plants and growth conditions}

Soybean (Glycine max L. Merr. cv. Williams) seeds were surface-sterilized with $96 \%$ ethanol (v/v) for $30 \mathrm{~s}$, further immersed in $\mathrm{H}_{2} \mathrm{O}_{2}(15 \%$, v/v) for $8 \mathrm{~min}$, washed thoroughly with sterile water and, finally, germinated in darkness at $30^{\circ} \mathrm{C}$. Selected seedlings were planted in autoclaved 1.5 1 Leonard jar assemblies filled with a sand-vermiculite mixture (1:1). Plants ( 2 per pot) were inoculated at sowing with $1 \mathrm{ml}$ of a single bacterial strain $\left(\sim 10^{8}\right.$ CFU.ml ${ }^{-1}$ ), provided with a mineral solution (Rigaud and Puppo, 1975) supplemented or not with a minimal concentration of nitrate $\left(4 \mathrm{mM} \mathrm{NO}_{3} \mathrm{~K}\right)$ to induce denitrification process without repress the nodule formation (Dogra and Dudeja, 1993). Plants were grown in a greenhouse with 
$16 \mathrm{~h}$ day photoperiod at $28^{\circ} \mathrm{C}$. After 35 -day-old plants were harvested. Dry weight was obtained by drying the fresh samples in an oven at $65^{\circ} \mathrm{C}$. When constant weight was reached, this was considered an indicator of complete drying.

\section{NO detection in nodules}

Plant growth conditions. Soybean seeds were disinfected, planted, inoculated and cultured as described above. The NO indicator dye DAF-2 DA (Calbiochem) was used to detect NO in nodule sections according to (Zafra et al. 2010). Nodules were detached from the roots of soybean plants, cut into halves by hand using a scalpel, immersed in $\mathrm{MES} / \mathrm{KCl} \mathrm{pH} 6.15$ for $10 \mathrm{~min}$, and transferred to $10 \mu \mathrm{M}$ DAF-2 DA for $10 \mathrm{~min}$. They were then washed with $\mathrm{MES} / \mathrm{KCl}$ buffer for $15 \mathrm{~min}$ and observed under the microscope. Parallel sets of samples were treated the same, although they were previously incubated for $1 \mathrm{~h}$ with the NOscavenger cPTIO (Sigma) in a concentration of $400 \mu \mathrm{M}$ in Tris-HCl $10 \mathrm{mM}$, pH 7.4. Negative controls were treated with MES-KCl buffer only, instead of with DAF-2 DA solution. Observations were carried out in a Nikon C1 confocal microscope using an Ar-488 laser source and different levels of magnification (20x to $60 \times)$. Multiple optical sections were captured and processed to generate 3-D reconstructions of the whole nodule surface. The fluorescent signal was obtained exclusively in the range of the 515-560 nm emission wavelengths, and recorded in green. Autofluorescence, mainly due to the presence of chlorophyll and other pigments and secondary metabolites, was isolated and displayed in red. Identical settings were used for image capture in both control/test experiments in order to ensure reproducibility and accurate quantification. Reconstructions were performed by using the Nikon EZ-C1 3.90 FreeViewer software. Quantification of fluorescence intensity in the infection area of nodules was made by using Image $\mathbf{J}$ free software.

This article is protected by copyright. All rights reserved. 


\section{$\mathrm{N}_{2} \mathrm{O}$ production by nodulated soybean roots}

To measure $\mathrm{N}_{2} \mathrm{O}$ produced by nodulated roots, plants were harvested from the Leonard jars and vermiculite was carefully removed. Then, roots were placed into $100 \mathrm{ml}$ bottles and closed with rubber septa and kept at room temperature. Gas samples were taken from the headspace using gas-tight syringes and injected into the gas chromatograph mentioned above. The $\mathrm{N}_{2} \mathrm{O}$ flux was recorded chronologically to check for linearity of $\mathrm{N}_{2} \mathrm{O}$ emissions, which were calculated within the linear interval between sampling times (Parkin and Kaspar 2006).

\section{Statistical analysis}

Statistical analyses were carried out by using the software package SPSS version17.0. Data were analyzed using Analysis of Variance (ANOVA) and the HSD Tukey pairwise comparisons. All tests were subjected to a $95 \%$ confidence limit.

\section{Results}

In silico analysis, Denitrification activity and $\mathrm{N}_{2} \mathrm{O}$ detection in free-living cells

We analyzed the whole genome sequences of strains CPAC7, CPAC15, E109 and USDA110 and the draft genomes of strains SEMIA 5019 and SEMIA 587, and we found that only in CPAC7 all genes described in the canonical denitrification pathway are present (napA, nirK and $n o r \mathrm{C}$ and nosZ); while CPAC15 and E109 have an incomplete pathway in which nosZ is absent. In the case of SEMIA 5019 and SEMIA 587, no sequences of any denitrification pathway genes were identified in their draft genomes (Table 3). With regard to denitrification activity, all strain were cultured from an initial optical density of $\left(\mathrm{OD}_{600}\right): 0,01$ and after 7 days all of them reached $\mathrm{OD}_{600} \sim 0,80$. This means Bradyrhizobium strains grow under microaerophilic conditions (i.e. $2 \%$ oxygen) with nitrate as the sole nitrogen source (Table S1). After incubation, all strains showed nitrate reductase $\left(\mathrm{NO}_{2}{ }^{-}\right.$production $)$activity with 
values varying from $2.52 \pm 0.5$ to $7.05 \pm 0.4 \mathrm{nM} \mathrm{NO}_{2}^{-}$produced. $\mathrm{h}^{-1}$. mg protein ${ }^{-1}$, corresponding to strains E109 and SEMIA 587, respectively (Table 1). They also displayed nitrite reductase $\left(\mathrm{NO}_{2}{ }^{-}\right.$consumption) activity, with values ranging from $0.92 \pm 0.1$ to $1.42 \pm$ $0.2 \mathrm{nM} \mathrm{NO}_{2}{ }^{-}$consumed. $\mathrm{h}^{-1}$. mg protein ${ }^{-1}$, corresponding to strains SEMIA 587 and CPAC15, respectively (Table 1). Nitrate and nitrite reductase activity evidenced the capability of the respective strains to metabolize nitrate and nitrite under microaerophilic conditions. All the bradyrhizobial strains consumed $\mathrm{NO}$ at rates ranging from $7.85 \pm 0.17$ to $61.94 \pm 2.9 \mathrm{nM}$ NO consumed.h ${ }^{-1}$. mg protein ${ }^{-1}$, shown by strains SEMIA 587 and E109, respectively. On the other hand, CPAC 7 and USDA 110 showed a lower NO production than the other strains, while E109 tripled the nM NO consumption by USDA 110. In all cases, NO reduction activity was detected. $\mathrm{N}_{2} \mathrm{O}$ accumulation was also detected after incubation for $7 \mathrm{~d}$. The lowest value was $0.15 \pm 0.01$ and the highest was $41.42 \pm n M N_{2} O \cdot h^{-1} \cdot m$ protein ${ }^{-1}$, by strains USDA 110 and E109, respectively. As expected, the amount of $\mathrm{N}_{2} \mathrm{O}$ accumulated by the wild type strain USDA 110 was very scarce (Table 1). Summarizing, in those strains belonging to B. diazoefficiens (USDA110 and CPAC 7) and containing nos $\mathrm{Z}$ gene, the values for $\mathrm{N}_{2} \mathrm{O}$ emissions were minimal; while the production by B. elkanii (SEMIA 587 and SEMIA 5019) was higher than the first ones but up to 6 times lower than that by B. japonicum (E109 and CPAC 15) (Table1).

\section{NO detection in soybean nodules}

In plants treated with minimal concentration of nitrate in culture medium, fluorometric NO detection detected varying fluorescence emission in nodules formed by bradyrhizobial strains, with values ranging from $70 \pm 5.02$ to $787 \pm 69.2$ relative fluorescence intensity units in the wild type USDA110 and the norC mutant GRC131, respectively (Table 2). Except for SEMIA 587, fluorescence intensity in the nodules formed by the remaining strains had higher 
values than those found in nodules formed by the wild type USDA110 and lower than those belonging to the norC mutant (Table 2).

Fluorescence due to NO emission was seen in nodules formed by GRC131 in plants treated with nitrate, but not in nodules by the same strain in plants watered with $\mathrm{N}$-free mineral nutrient solution (Figure 1). Treatment of the nodules with c-PTIO prior to the imaging of NO production resulted in the suppression of fluorescence emission, which indicates that the response was representative of bacterial NO production (Figure 2). Nodules from nitratetreated plants formed by USDA 110, E109, CPAC15, CPAC7, SEMIA 587 and SEMIA 5019 strains emitted fluorescence, albeit with different intensities. As expected, the mutant norC strain GRC131 showed maximum DAF-2DA staining (Figure 3).

\section{$\mathrm{N}_{2} \mathrm{O}$ emissions from inoculated soybean roots}

Nodules from soybean roots inoculated with strains USDA 110, GRZ 3035, E109, CPAC15, CPAC7, SEMIA 587 and SEMIA 5019 produced $\mathrm{N}_{2} \mathrm{O}$, albeit at different concentrations (Table 2). Nodulated roots of SEMIA 5019 and E109 were the highest $\mathrm{N}_{2} \mathrm{O}$ producers, with values that were, respectively, 26.2 times and 18.4 times that of the $\mathrm{N}_{2} \mathrm{O}$ emitted by the wild type strain USDA $110\left(83 \pm 6.9 \mathrm{nM} \mathrm{N}_{2} \mathrm{O} \mathrm{h}^{-1}\right.$.nodules fresh weight $\left.{ }^{-1}\right)$. Moreover, the amount of $\mathrm{N}_{2} \mathrm{O}$ produced by either E109 or SEMIA 5019 was higher than that produced by the nosZ 3035 mutant, which lacks nitrous oxide reductase activity (Table 2).

\section{Discussion}

In silico and molecular analysis of denitrification genes

Molecular analyses were performed to identify the presence of denitrification genes in Bradyrhizobium strains. In this manuscript we found that the reference strain $B$. diazoefficiens 
USDA 110 has the full set of genes for the denitrification pathway, as it was previously reported by (Bedmar et al.2005). In our experimental conditions, no amplification of any denitrification pathway gen was obtained for B. elkanii SEMIA 587 and SEMIA 5019 (Figure 1S), but the presence of such genes was confirmed in silico and in vitro (Table S2) for $B$. diazoefficiens CPAC7 and B. japonicum CPAC15 and E109. We broaden the scope of our study and analyzed the genome sequences of B. elkanii strains USDA 3259, 3254, 94 and 76; WSM1741 and 2783;

BLY6-1 and 3-8; CCBAU 43297 and 05737; UASWS1015 and WSM1741 by the use of MicroScope (http://www.genoscope.cns.fr/agc/microscope/home/index.php); KEEG (https://www.genome.jp/kegg/) and BLAST (http://ncbi.nlm.nih.gov/BLAST) databases. In the case of USDA 3259, 3254 and 94 we found homologous sequences for the canonical nap A, but we did not found any sequence for nirK, nor $\mathrm{C}$ and $n o s \mathrm{Z}$ in none of such genomes. In the case of WSM 2783 we found homologous sequences for the canonical napA, nirK and nor $C$ but we did not found any sequence for nos $\mathrm{Z}$ in the genome. These results, allows us to infer that different Bradyrhizobium species have particular denitrification genes and pathways, were $B$. diazoefficiens has all the canonical denitrification pathway and consequently all the related genes; B. japonicum has an incomplete pathway including napA, nirK and norC, but excluding nosZ and four of twelve strains of B. elkanii have napA as the unique denitrification gene of the canonical pathway; while only one has an incomplete pathway including napA, nirK and norC.

\section{Denitrification activities in free-living cells}

The denitrification process consists in the reduction of nitrate/nitrite to $\mathrm{N}_{2}$ (Zumft 1997). Previous reports have noted that not all rhizobial strains are able to grow in denitrifying conditions (Monza et al. 2006; Zhong et al. 2009). In our study, the best adaptation to the 
microaerophilic conditions was observed for USDA110. However, all the strains were able to grow under denitrifying conditions. They survive and assimilate either nitrate or nitrite as a final electron acceptor, which implies the induction of denitrifying genes under these conditions to carry out an assimilation process (Bedmar et al. 2005). Under our experimental conditions, nitrate reduction activity was observed to be further induced than that of nitrite reduction activity (Table 1). Sánchez et al. 2010, reported that MV-dependent nitrate and nitrite reductase activities in free-living denitrifying conditions were about 10 times higher than those observed under aerobic conditions. In this report, the $88 \%$ and $93 \%$ of the nitrate reductase and nitrite reductase activities detected in anaerobically grown cells correspond to Nap and NirK enzymes, respectively. Nevertheless, all the strains were able to produce and consume nitrite, expressed as an induction and activation of Nar and Nir. The determination of nitrate and nitrite reductase activity, allows us to infer the presence of napA and nirK genes in B. diazoefficiens CPAC 7 and B. japonicum E109 and CPAC 7, but not in B. elkanii SEMIA 587 and 5019 in which according to the in silico and in vitro analysis other unravel mechanism should be operating for denitrification process. The reduction of nitrate to nitrite is catalyzed by nitrate reductase and encoded by the napA gene in B. japonicum USDA110, while free-living cells of the napA mutant are unable to reduce nitrate (Delgado et al. 2003). According to Velasco et al. 2001, the nirK gene in B. diazoefficiens USDA110 strain is required for breathing in anaerobic conditions with nitrate as a single source of nitrogen. As well as the in silico analysis for E109, CPAC15 and CPAC7, the presence of nirK can be deduced for these strains. Zumft, 1997 and Sánchez et al. 2010, reported that the denitrification process is the main pathway for oxide nitric production in free-living bacteria. Under our experimental conditions, all the strains accumulated NO after the addition of nitrite inside the chamber. Velasco et al. 2001 reported that cells of $B$. diazoefficiens USDA 110, which are mutants for the nirK o nor $\mathrm{C}$ genes, accumulated nitrite and nitric oxide, 
respectively, when they were grown in anaerobic conditions with nitrate as a nitrogen source. In all cases in our results, there was an activation of the nitrite reductase enzyme (Nir) and the nirK gene codified this activity. Although they just provide anaerobic conditions in measuring, this information indicates that the capacity of rhizobia to produce large amounts of $\mathrm{N}_{2} \mathrm{O}$ in denitrifying conditions could be very variable but a fluxes trend is continuing.

Fernández et al. 2008 described the denitrifying ability of Bradyrhizobium isolates from five Argentinian soybean-cultivated soils. This study showed that 41 out of the 250 isolates exhibited behavior typical of true respiratory denitrifiers. This pattern has been correlated with complete denitrification and is not common in rhizobial strains, which lack $\mathrm{N}_{2} \mathrm{O}$ reductase (Hallin et al. 2017). As reported by Sameshima-Saito et al. 2006a, who evaluated the conversion of ${ }^{15} \mathrm{~N}-\mathrm{N}_{2} \mathrm{O}$ to ${ }^{15} \mathrm{~N}-\mathrm{N}_{2}$ and $\mathrm{N}_{2} \mathrm{O}$ reductase activity in USDA 110 and USDA110 nozZ-lacking strains, the wild type strain showed $\mathrm{N}_{2} \mathrm{O}$ reductase activity, whereas the nosZ mutant did not. Out of the strains analyzed in this study, only CPAC7 can be considered a complete denitrifier and $\mathrm{N}_{2} \mathrm{O}$ lower producer, which confirms the low abundance of rhizobia capable of emitting molecular nitrogen as a final product.

\section{Nitric oxide and nitrous oxide production in Bradyrhizobium-soybean interaction}

The correlation between NO production and its reduction to nitrous oxide has not been clarified, while for $\mathrm{NO}_{2}{ }^{-}$to $\mathrm{NO}$ reduction numerous alternative pathways through enzymatic or non-enzymatic conversion have been found in plants (Gupta et al. 2011; Mur et al. 2013) and bacteria (Zumft 1997). The bacterial pathway has been reported as the main route for NO production and it occurs both in free-living bacteria under microaerophilic conditions and soybean nodules (Meilhoc et al. 2011). Thus, it has been proven that there are several NO detoxification sources (in free-living cells and symbiotic conditions) and that NO is not only 
reduced to nitrous oxide (Sánchez et al. 2010; Cabrera et al. 2016). As can be observed in Figure 3, under our conditions fluorometric NO detection showed some endogenous NO accumulation in nor $\mathrm{C}$ nodules from plants that were not treated with nitrate- Moreover, the presence of nitrate in the mineral solution increased NO production. However, our results stand in contrast with the report by (Sánchez et al. 2010), who could not detect differences in nodular NO accumulation between plants inoculated either with B. diazoefficiens USDA110 or GRC131 in the presence of nitrate. They found that application of flooding allowed the detection of NO accumulation, mostly in GRC131 nodules, and that it stimulated NO production by USDA 110 .

Nitrous oxide $\left(\mathrm{N}_{2} \mathrm{O}\right)$ is one of the three main biogenic greenhouse gases (GHGs), and agriculture represents close to $30 \%$ of the total $\mathrm{N}_{2} \mathrm{O}$ emissions (Tortosa et al. 2015).Various authors have reported that leguminous plants associated to Bradyrhizobium sp. can fix nitrogen from the atmosphere but also emit $\mathrm{N}_{2} \mathrm{O}$ (Duxbury et al. 1982; Inaba et al. 2009). In the present study, treatments inoculated with USDA110 and CPAC7 strains had very low $\mathrm{N}_{2} \mathrm{O}$ production values in comparison with all the other strains used, which are considered incomplete denitrifiers that lack the nosZ gene (Table 3). In this sense, Itakura et al. 2013 reported that in pure culture and pot experiments $\mathrm{N}_{2} \mathrm{O}$ emission was lower in $\operatorname{nos} Z^{+}$ strains and $n o s Z^{++}$strains (mutants with increased nitrous oxide reductase activity) of Bradyrhizobium japonicum than in nos $Z^{-}$strains (mutants lacking nitrous oxide reductase activity).

According to our results, (summarized in Table 3), Bradyrhizobium-soybean interaction $\mathrm{N}_{2} \mathrm{O}$ production was higher for CPAC15, E109 and SEMIA 587 treatments. All these groups are commercially used as the active ingredient in the formulation of bioproducts for soybean [Glycine max L. (Merr.)] in Argentina and Brazil. Because of this, the genomes of CPAC15 
and E109 have been sequenced, and our results can confirm that they are incomplete denitrifying rhizobia. In this respect, several authors have reported that various strains of Bradyrhizobium that lack nosZ produce nitrous oxide as a final denitrification product, and this kind of bacteria are found in agricultural soils (Sameshima et al. 2004; Fernández et al. 2008). Natural Bradyrhizobium populations which lack the nos $\mathrm{Z}$ gene and $\mathrm{N}_{2} \mathrm{O}$ reductase activity are often dominant in the soils of soybean fields (Chèneby et al. 1998; SameshimaSaito et al. 2006a). Considering the vast extension of soil cultivated with soybean in South America, nitrous oxide may be emitted from the nodulated soybean roots, and the legumeBradyrhizobium symbiosis could play an important role in nitrous oxide emissions, thus contributing to global warming (IPCC 2006).

\section{Denitrification activity for SEMIA 5019 and SEMIA 587}

Even though in SEMIA 5019 and SEMIA 587 we did not amplify the canonical denitrification genes by PCR methodology, these strains do have nitrate and nitrite reduction activity capacity and produce nitric oxide and nitrous oxide in our experimental conditions

(Table 1 and Figure S1). Sameshima-Saito et al. 2006b reported absence of nir, nor and nos genes in $\mathrm{B}$. elkanii and $\mathrm{NO}_{2}{ }^{-}$and $\mathrm{NO}_{3}{ }^{-}$as denitrification end products for these strains, while our results evidenced $\mathrm{N}_{2} \mathrm{O}$ as denitrification end products. Also, they found napA gen through Southern hybridization in B. elkanii USDA94, which coincides with in silico results of B. elkanii USDA 3259, 3254 and WSM2783, but contrasting with our in silico and in vitro results for SEMIA 5019 and SEMIA 587. An unique report related to $\mathrm{N}_{2} \mathrm{O}$ production Bradyrhizobium sp. and B. elkanii strains found that SEMIA 587 strain produced lower $\mathrm{N}_{2} \mathrm{O}$ values than USDA110 and CPAC7 (Nascimento 2011, cited by Alves et al. 2016). B. elkanii SEMIA 587 and SEMIA 5019 have no denitrification genes codified in their genomes, but they have capacity to reduce nitrate and produce nitrous oxide. In this sense, nitrate, nitrite 
and nitric oxide reduction activity, as well as $\mathrm{N}_{2} \mathrm{O}$ accumulation was demonstrated in this manuscript in two strains of B. elkanii. Fernández et al. 2008 mentioned that not all denitrification genes were detected in Bradyrhizobium isolates, but gas chromatography revealed that these strains produced $\mathrm{N}_{2} \mathrm{O}$. Inefficient amplification reactions might have occurred due to differences between the nucleotide sequences of the primers and genetic sequences for the enzymes among denitrifying bacteria (Chèneby et al. 1998; Fernández et al. 2008). An alternative explanation for the inability of amplify napA, nirK, norC and norC in SEMIA 5019 and SEMIA 587 should be attributed to the genes' polymorphism (Jaton et al., 2010), which might inhibit the target sequences amplification proposed by Fernandez et al., (2008). Even when in silico results did not indicate presence of denitrification genes of the canonical pathway for almost all strains of $B$. elkanii, we shall not exclude an inherent limitation of the PCR methodology affecting the amplification of those genes under our experimental conditions. Future research could reveal the presence of these genes or an alternative pathway involved in the denitrification and $\mathrm{N}_{2} \mathrm{O}$ emissions for B. elkanii.

This is the first study to describe and confirm the incomplete denitrification pathway in most strains used in the production of inoculants for soybean in South America in particular, and it constitutes one step in the process of establishing the role of Bradyrhizobium strains and nitrous oxide emissions in global climate change.

\section{Acknowledgments}

Financial support was obtained from the Universidad Nacional de Río Cuarto and Consejo Nacional de Investigación Científico-Tecnológica (CONICET) from Argentina, the FEDERcofinanced Project AGR2012-1968 from Consejería de Economía, Innovación y Ciencia (Junta de Andalucía, Spain) and from the CSIC-sponsored I-COOP2014 project 
COOPA20069. We thank J. Chacón for technical assistance. MO and JG are PhD students at the UNRC granted by CONICET.

\section{Conflicts of Interest}

The authors declare no competing interests.

\section{References}

Alves, B.J.R., Urquiaga, S. Jantalia, C.P. and Boddey, R.M. (2016). Influência de fungos e bactérias na eficiência da fertilização nitrogenada e na emissão de $\mathrm{N}_{2} \mathrm{O}$ para a atmosfera. In: Fatima Maria de Souza Moreira; Maria Catarina Megumi Kasuya. (Org.). Fertilidadee biologia do solo: Integração e tecnologia para todos. 1ed.Viçosa: Soc Bras Ciênc Sol 1, 197226. ISBN: 978-85-86504-17-4

Baudouin, E., Pieuchot, L. Engler, G. Pauly. and N.Puppo A. (2006). Nitric oxide is formed in Medicago truncatula-Sinorhizobium meliloti functional nodules. Mol Plant Microbe Interact 19, 970-975. doi: 10.1094/MPMI-19-0970.

Bedmar, E.J., Robles, E.F. and Delgado, M.J. (2005). The complete denitrification pathway of the symbiotic, nitrogen-fixing bacterium Bradyrhizobium japonicum. Biochem Soc Trans 33, 141-144. doi: 10.1042/BST0330141.

Bergersen, F.J. (1977) A treatise on dinitrogen fixation. In: Hardy RW, Silver W (eds) Biology. Wiley, New York, 519-556.

Besson-Bard, A., Pugin, A. and Wendehenne, D. (2008). New insights into nitric oxide signaling in plants. Annu Rev Plant Biol 59, 21-39. doi:

10.1146/annurev.arplant.59.032607.092830.

This article is protected by copyright. All rights reserved. 
Bolsa de Cereales de Buenos Aires, 2018. Informe de cierre de campaña de soja. Website: http://www.bolsadecereales.com/ver-cierre-de-campana-105. Date of the last access: July,2018.

Bueno, E., Mesa, S. Bedmar, E.J. Richardson, D.J. and Delgado, M.J. (2012) Bacterial adaptation of respiration from oxic to microoxic and anoxic conditions: Redox control. Antioxid. and Redox Signal 16, 819-852. doi: 10.1089/ars.2011.4051

Cabrera, J. Salas, A. Torres, M. J. Bedmar, E.J. Richardson, D.J. Gates, A.J. and Delgado, M.J. (2016). An integrated biochemical system for nitrate assimilation and nitric oxide detoxification in Bradyrhizobium japonicum. Biochem J 473 (3), 297-309. doi: 10.1042/BJ20150880.

Campos, B.C., Hungria, M. and Tedesco, V. (2001). Eficiência da fixação biológica de $\mathrm{N}_{2}$ por estirpes de Bradyrhizobium na soja em plantio direto. Rev. Bras. Ciênc. Solo 25 (3), 583-592. doi: 10.1590/S0100-06832001000300007.

Chèneby, D., Hartmann, A. Hénault, C. Topp, E. and Germon, J. C. (1998). Diversity of denitrifying microflora and ability to reduce $\mathrm{N}_{2} \mathrm{O}$ in two soils. Biol Fertil Soils 28 (1), 19-26. doi: $10.1007 / \mathrm{s} 003740050458$.

Cueto, M., Hernández-Perera, O. Martín, R. Bentura, M.L. Rodigo, J. Lamas, S. and Golvano, M.P. (1996) Presence of nitric oxide synthase activity in roots and nodules of Lupinus albus. FEBS Lett 398, 159-164. https://doi.org/10.1016/S0014-5793(96)01232-X del Giudice, J., Cam, Y. Damiani, I. Fung-Chat, F. Meilhoc, E. Bruand, C. Brouquisse, R. Puppo, A. and Boscari, A.(2011) Nitric oxide is required for an optimal establishment of the Medicago truncatula-Sinorhizobium meliloti symbiosis. New Phytol. 191,405-417. doi: 10.1111/j.1469-8137.2011.03693.x

Delgado, M.J., Bonnard, N. Tresierra-Ayala, A. Bedmar E.J. and Müller, P. (2003).The Bradyrhizobium japonicum napEDABC genes encoding the periplasmic nitrate reductase are 
essential for nitrate respiration. Microbiology 149 (Pt 12), 3395-3403. doi: 10.1099/mic.0.26620-0.

Dogra R.C. and Dudeja S.S. (1993). Fertilizer N and nitrogen fixation in legume-Rhizobium symbiosis. Ann Biol 9(2): 149 -164.

Duxbury, J.M., Bouldin, D.R. Terry, R.E. and Tate R.L. (1982) Emissions of nitrous oxide from soils. Nature 298,462-464. DOI:10.1038/298462a0

Fernández, L.A., Perotti, E.B. Sagardoy, M.A. and Gómez, M.A. (2008) Denitrification activity of Bradyrhizobium sp. isolated from Argentine soybean cultivated soils. World $J$ Microbiol Biotechnol. 24(11), 2577-2585. doi: 10.1007/s11274-008-9828-х.

Fukudome, M., Calvo-Begueria, L. Osuki, K. Rubio, M.C. Murakami, E. Nagata M. Kucho, K. Sandal, N. Stougaard, J. Becana, M. and Uchiumi, T. (2016) Hemoglobin LjGlb1-1 is involved in nodulation and regulates the level of nitric oxide in the Lotus japonicusMesorhizobium loti symbiosis. J Exp Bot 67, 5275-5283. doi: 10.1093/jxb/erw290 Gupta, K.J., Fernie, A.R. Kaiser. W.M. and van Dongen, J.T. (2011) On the origins of nitric oxide. Trends Plant Sci 16, 160-168. doi: 10.1016/j.tplants.2010

Hallin, S., Philippot, L. Löffler, F.E. Sanford, R.A. and Jones, C.M. (2017) Genomics and ecology of novel $\mathrm{N}_{2} \mathrm{O}$-reducing microorganisms. Trends Microbiol 26, 43-55. doi: 10.1016/j.tim.2017.07.003

Hichri, I., Boscari, A. Castella, C. Rovere, M. Puppo, A. and Brouquisse, R. (2015) Nitric oxide: a multifaceted regulator of the nitrogen-fixing symbiosis. J Exp Bot 66 (10), 28772887. doi: 10.1093/jxb/erv051.

Hirayama, J., Eda, S. Mitsui, H. and Minamisawa, K. (2011) Nitrate-dependent $\mathrm{N}_{2} \mathrm{O}$ emission from intact soybean nodules via denitrification by Bradyrhizobium japonicum bacteroids. Appl Environ Microbiol 77 (24), 8787-8790. doi: 10.1128/AEM.06262-11. 
Inaba, S., Tanabe, K. Eda, S. Ikeda, S. Higashitani, A. Mitsui, H. and Minamisawa, K. (2009) Nitrous oxide emission and microbial community in the rhizosphere of nodulated soybeans during the late growth period. Microbes and environ 24 (1), 64-67. https://doi.org/10.1264/jsme2.ME08544

IPCC (2006) IPCC guidelines for national greenhouse gas inventories. In: Eggleston, H.S. Buendia, L. Miwa, K. Ngara, T. Tanabe, K. (Eds.), Agriculture, Forestry and Other Land Use. Prepared by the National Greenhouse Gas Inventories Programme, vol. 4. IGES, Japan. Itakura, M. Uchida, Y. Akiyama, H. Hoshino, Y.T. Shimomura, Y. Morimoto, S. Tago, K. Wang, Y. Hayakawa, C. Uetake,Y. Sánchez, C. Eda, S. Hayatsu, M. and Minamisawa. K. (2013) Mitigation of nitrous oxide emissions from soils by Bradyrhizobium japonicum inoculation. Nat Clim Chang 3(3), 208-212. doi: 10.1038/nclimate1734.

Jaton, K., Ninet, B., Bille, J. and Greub, G. (2010). False-negative PCR result due to gene polymorphism: the example of Neisseria meningitidis. J Clin Microbiol 48, 4590-4591. Jensen, E.S., Peoples, M.B. Boddey, R.M. Gresshoff, P.M. Hauggaard-Nielsen, H. and Alves, B.J.R. (2012) Legumes for mitigation of climate change and the provision of feedstock for biofuels and biorefineries. A review. Agron Sustain Dev 32, 329. doi:10.1007/s13593-0110056-7

Lewis, G., Schrire, B. Mackinder, B. and Lock, M. (2005) Legumes of the World. Royal Botanic Gardens Kew. 577.

Meade, B., Puricelli, E., McBride, W., Valdes, C., Hoffman, L., Foreman. and L., Dohlman, E. (2016) Corn and Soybean Production Costs and Export Competitiveness in Argentina, Brazil and the United States. Economic Information Bulletin 154. Washington, DC. Economic Research Service, US Department of Agriculture.

This article is protected by copyright. All rights reserved. 
Meakin, G.E., Jepson, B.J.N. Richardson, D. J. Bedmar, E. J. and Delgado, M.J.(2006) The role of Bradyrhizobium japonicum nitric oxide reductase in nitric oxide detoxification in soybean root nodules. Biochem Soc Trans 34 (Pt 1), 195-196. doi: 10.1042/BST0340195. Meilhoc, E., Boscari, A. Bruand, C. Puppo, A. and Brouquisse, R.(2011) Nitric oxide in legume-rhizobium symbiosis. Plant Sci 181 (5), 573-581. doi:

10.1016/j.plantsci.2011.04.007.

Mesa, S., Velasco, L. Manzanera, M.E. Delgado, M.J. and Bedmar, E.J. (2002)

Characterization of the norCBQD genes, encoding nitric oxide reductase, in the nitrogen fixing bacterium Bradyrhizobium japonicum. Microbiology 148 (Pt 11), 3553-3560. doi: 10.1099/00221287-148-11-3553.

Monza,J., Irisarri, P. Díaz, P. Delgado, M.J. Mesa, S.and Bedmar E.J. (2006) Denitrification ability of rhizobial strains isolated from Lotus sp.. Antonie Van Leeuwenhoek 89, 479-484. https://link.springer.com/article/10.1007/s10482-005-9046-6 Mur, L.A., Mandon, J. Persijn, S. Cristescu, S.M. Moshkov, I.E. Novikova, G.V. Hall, M.A. Harren, F.J. Hebelstrup, K.H. and Gupta, K.J. (2013) Nitric oxide in plants: an assessment of the current state of knowledge. AoB Plants 5, 052. doi: 10.1093/aobpla/pls052.

Nagata, M.; Murakami, E. Shimoda, Y. Shimoda-Sasakura, F. Kucho, K. Suzuki, A. Abe, M. Higashi, S. and Uchiumi, T.(2008) Expression of a Class 1 Hemoglobin Gene and Production of Nitric Oxide in Response to Symbiotic and Pathogenic Bacteria in Lotus japonicus. Mol Plant Microbe Interact 21(9), 1175-1183. doi: 10.1094/MPMI-21-9-1175.

Nascimento, E.C. (2011) Potencial desnitrificador de estirpes de Bradyrhizobium recomendadas para a cultura da soja. Seropédica, Universidade Federal Rural do Rio de Janeiro.77. (Dissertaçao de Mestrado).

Nicholas, D. J. and Nason, A. (1954) Mechanism of action of nitrate reductase from Neurospora. J Biol Chem 211 (1), 183-197. 
Okada, N., Nomura, N. Nakajima-Kambe, T. and Uchiyama, H. (2005) Characterization of the aerobic denitrification in Mesorhizobium sp. strain NH-14 in comparison with that in related rhizobia. Microbes and environ 20, 208-215. https://doi.org/10.1264/jsme2.20.208 Parkin, T.B. and Kaspar, T.C. (2006) Nitrous oxide emissions from corn-soybean systems in the midwest. J Environ Qual 35 (4), 1496-1506. doi: 10.2134/jeq2005.0183.

Pauly, N. (2006) Reactive oxygen and nitrogen species and glutathione: key players in the legume-Rhizobium symbiosis. J Exp Bot 57 (8), 1769-1776. doi: 10.1093/jxb/erj184.

Peix, A., Ramírez-Bahena, MH. Flores-Félix, J.D. La Alonso de Vega, P. Rivas, R. and Mateos, P.F. (2015) Revision of the taxonomic status of the species Rhizobium lupini and reclassification as Bradyrhizobium lupini comb. nov. Int J Syst Evol Microbiol 65 (Pt 4), 1213-1219. doi: 10.1099/ijs.0.000082.

Regensburger B, Hennecke H. (1983) RNA polymerase from Rhizobium japonicum. Arch Microbiol 135,103-109.

Rigaud, J. and Puppo, A. (1975) Indole3-acetic Acid Catabolism by Soybean Bacteroids. J Gen Microbiol 88, 223-228.

Robles, E.F., Sánchez, C. Bonnard, N. Delgado, M.J. and Bedmar, E. J.(2006) The Bradyrhizobium japonicum napEDABC genes are controlled by the FixLJ-FixK(2)-NnrR regulatory cascade. Biochem Soc Trans 34 (Pt 1), 108-110. doi: 10.1042/BST0340108. Sameshima, R. Isawa, T. Sadowsky, M.J. Hamada, T. Kasai, H. Shutsrirung, A. Mitsui H. and Minamisawa K. (2003) Phylogeny and distribution of extra-slow- growing Bradyrhizobium japonicum harboring high copy numbers of of RSalpha, RSbeta and IS1631. FEMS Microbiol Ecol 44 (2), 191-202. doi: 10.1016/S0168-6496(03)00009-6.

Sameshima-Saito, R., Chiba, K. and Minamisawa, K. (2004) New method of denitrification analysis of Bradyrhizobium field isolates by gas chromatographic determination of ${ }^{15} \mathrm{~N}$ labeled $\mathrm{N}_{2}$. Appl Environ Microbiol 70:2886-2891. doi: 10.1128/AEM.70.5.2886-2891.2004 
Sameshima-Saito., R. Chiba, K. Hirayama, J. Itakura, M. Mitsui, H. Eda, S. and

Minamisawa, K. (2006a) Symbiotic Bradyrhizobium japonicum Reduces $\mathrm{N}_{2} \mathrm{O}$ Surrounding the Soybean Root System via Nitrous Oxide. Reductase. Appl Environ Microbiol 72 (4), 2526-2532. doi: 10.1128/AEM.72.4.2526-2532.2006.

Sameshima-Saito, R., Chiba, K. and Minamisawa, K. (2006b) Correlation of denitrifying capability with the existence of nap, nir, nor and nos genes in diverse strains of soybean Bradyrhizobia. Microbes and environ 21, 174-184. https://doi.org/10.1264/jsme2.21.174 Sánchez, C., Gates, A.J. Meakin, G.E. Uchiumi, T. Girard, L. Richardson, D.J. Bedmar, E.J. and Delgado, M.J. (2010) Production of nitric oxide and nitrosylleghemoglobin complexes in soybean nodules in response to flooding. Mol Plant Microbe Interact 23 (5), 702-711. doi: 10.1094/MPMI-23-5-0702.

Shamseldin, A. Abdelkhalek, A. and Sadowsky, M.J.(2017) Recent changes to the classification of symbiotic, nitrogen-fixing, legume-associating bacteria: a review. Symbiosis 71, 91-109. https://doi.org/10.1007/s13199-016-0462-3

Siqueira, A.F., Ormeño-Orrillo, E. Souza, R.C. Rodrigues, E.P. Almeida, L.G.P. Barcellos, F.G. Batista, J.S. Nakatani, A.S. Martínez-Romero, E. Vasconcelos, A.T. and Hungria, M (2014) Comparative genomics of Bradyrhizobium japonicum CPAC 15 and Bradyrhizobium diazoefficiens CPAC 7: elite model strains for understanding symbiotic performance with soybean. BMC genomics 15, 420. doi: 10.1186/1471-2164-15-420.

Torres, D., Revale, S. Obando, M. Maroniche, G. Paris, G. Perticari, A. Vazquez, M. Wisniewski-Dyé, F. Martínez-Abarca, F. and Cassán, F. (2015) Genome Sequence of Bradyrhizobium japonicum E109, One of the Most Agronomically Used Nitrogen-Fixing Rhizobacteria in Argentina. Genome Announc 3,1. doi: 10.1128/genomeA.01566-14.

This article is protected by copyright. All rights reserved. 
Tortosa, G., Hidalgo, A. Salas, A. Bedmar, E.J. Mesa, S. and Delgado, M.J. (2015) Nitrate and flooding induce $\mathrm{N}_{2} \mathrm{O}$ emissions from soybean nodules. Symbiosis 67 (1-3), 125-133. doi: 10.1007/s13199-015-0341-3.

United States Department of Agriculture, 2017. Website: https://www.fas.usda.gov/. Date of the last access: April,2018.

Velasco, L., Mesa, S. Delgado, M.J. and Bedmar, E.J. (2001) Characterization of the nirK gene encoding the respiratory, $\mathrm{Cu}$-containing nitrite reductase of Bradyrhizobium japonicum. Biochim Biophys Acta 1521 1(3), 130-134. https://doi.org/10.1016/S0167-4781(01)00279-2 Velasco, L., Mesa, S. Xu, C. Delgado, M.J. and Bedmar, E.J. (2004) Molecular characterization of nosRZDFYLX genes coding for denitrifying nitrous oxide reductase of Bradyrhizobium japonicum. Antonie van Leeuwenhoek 85 (3), 229-235. doi: 10.1023/B:ANTO.0000020156.42470.db.

Zafra, A., Rodríguez-García, M.I. and Alché. J.D. (2010) Cellular localization of ROS and NO in olive reproductive tissues during flower development. BMC Plant Biol 10, 36. https://doi.org/10.1186/1471-2229-10-36

Zhong, Z., Lemke, R. and Nelson, L.M. (2009) Nitrous oxide emissions associated with nitrogen fixation by grain legumes. Soil Biol Biochem 41 (11), 2283-2291. doi: 10.1016/j.soilbio.2009.08.009.

Zumft, W.G. (1997). Cell biology and molecular basis of denitrification. Microbiol Mol Biol $\operatorname{Rev} 4,533-616$.

This article is protected by copyright. All rights reserved. 


\section{Tables headers}

Table 1. Nitrate reductase (Nap) or $\mathrm{NO}_{2}^{-}$production; Nitrite reductase (Nir) or $\mathrm{NO}_{2}^{-}$ consumption; nitric oxide reductase (Nor) or NO consumption activity and NO accumulation in Bradyrhizobium strains. Cells were grown in Bergersen's minimal medium with $10 \mathrm{mM}$ $\mathrm{NO}_{3} \mathrm{~K}$ as the sole nitrogen source under $2 \% \mathrm{O}_{2}$ for $7 \mathrm{~d}$. Values represent the mean \pm standard error of 4 replicates.

Table 2. Nitric oxide (NO) and nitrous oxide $\left(\mathrm{N}_{2} \mathrm{O}\right)$ production by nodules of soybean $(G$. $\max$ L.) inoculated with Bradyrhizobium strains. The wild type strain USDA 110 and its mutant derivatives norC GRC131 and nosZ GRZ 3035 were used as control. Values represent the mean \pm standard error of 4 replicates.

Table 3. Correlation between presence/absence of denitrification pathway genes and nitrous oxide production in both, free living cells of Bradyrhizobium and nodulated soybean roots.

\section{Supplementary Tables}

Table S1. Maximum growth of B. japonicum E109 and CPAC 15; B. elkanii SEMIA 5019 and SEMIA 587 and B. diazoefficiens CPAC 7 cultured under microaerophilic conditions in Bergersen's minimal medium (Bergersen, 1977).

Table S2. Results of the molecular analysis for denitrification pathway genes in B. japonicum E109 and CPAC 15; B. elkanii SEMIA 5019 and SEMIA 587 and B. diazoefficiens CPAC 7. The genes napA, nirK, norB and nos $Z$ were amplified using the specific primers described by Fernández et al. (2008). 


\section{Legend to Figures}

Figure 1. Nitric oxide production in nodules of soybean $(G . \max$ L.) inoculated with $B$. diazoefficiens GRC131 lacking norC. Plants were watered with mineral nutrient solution containing (A) or not (B) $5 \mathrm{mM} \mathrm{NO}{ }_{3} \mathrm{~K}$. NO production was imaged by DAF-2DA staining (green fluorescence). A' and B', images under bright field. Bars represent $500 \mu \mathrm{m}$.

Figure 2. Nitric oxide production in nodules of soybean $(G . \max$ L.) inoculated with $B$. diazoefficiens GRC 131 lacking norC. Plants were watered with mineral nutrient solution containing $5 \mathrm{mM} \mathrm{NO} 3 \mathrm{~K}$. NO production was imaged by DAF-2DA staining (green fluorescence). Nodules were treated (A) or not (B) with cPTIO. $\mathrm{A}^{\prime}$ and $\mathrm{B}^{\prime}$, images under bright field. Bars represent $500 \mu \mathrm{m}$.

Figure 3. Nitric oxide production in nodules of soybean (G. $\max$ L.) inoculated with Bradyrhizobium strains USDA 110 (A), E109 (B); SEMIA 5019 (C), CPAC15 (D), CPAC7 (E), SEMIA 587 (F) and GRC131 (G) lacking norC. A', B', C', D', E', F' and G', images under bright field. Plants were watered with mineral nutrient solution containing $5 \mathrm{mM}$ $\mathrm{NO}_{3} \mathrm{~K}$. NO production was imaged by DAF-2DA staining (green fluorescence). Bars represent $500 \mu \mathrm{m}$.

\section{Supplementary Figure}

Figure 1S. Agarose gel showing PCR amplification of napA, nirK, norC and nos $\mathrm{Z}$ genes from B. elkanii strains SEMIA 587 and SEMIA 5019 using the primers proposed by Fernández et al. (2008). Lanes: DNA marker (1Kb); B. dizoefficiens USDA110 (positive control); SEMIA 5019 and SEMIA 587. 
Table 1.

\begin{tabular}{|c|c|c|c|c|}
\hline strain & $\begin{array}{l}{ }^{(*)} \text { Nap activity or } \\
{ }^{(* *)} \mathrm{NO}_{2}^{-} \text {production }{ }^{(1)}\end{array}$ & $\begin{array}{l}{ }^{(*)} \text { Nir activity or } \\
{ }^{(* *)} \mathrm{NO}_{2}^{-} \text {consumption }{ }^{(2)}\end{array}$ & $\begin{array}{l}{ }^{(*)} \text { Nor activity or } \\
{ }^{(* *)} \text { NO consumption } \\
(3)\end{array}$ & $\mathrm{N}_{2} \mathrm{O}$ accumulation ${ }^{(4)}$ \\
\hline USDA 110 & $5.52^{\mathrm{b}} \pm 0.4$ & $1.34^{\mathrm{ab}} \pm 0.2$ & $22.20^{c} \pm 1.4$ & $0.15^{\mathrm{e}} \pm 0.01$ \\
\hline E109 & $2.52^{\mathrm{d}} \pm 0.5$ & $1.23^{b} \pm 0.3$ & $61.94^{\mathrm{a}} \pm 2.9$ & $41.42^{\mathrm{a}} \pm 2.4$ \\
\hline CPAC 15 & $7.04^{\mathrm{a}} \pm 0.4$ & $1.42^{\mathrm{a}} \pm 0.2$ & $11.28^{\mathrm{c}} \pm 1.1$ & $12.59^{\mathrm{b}} \pm 0.7$ \\
\hline CPAC 7 & $4.05^{\mathrm{c}} \pm 0.3$ & $1.10^{\mathrm{bc}} \pm 0.1$ & $33.35^{\mathrm{b}} \pm 2.2$ & $0.19^{\mathrm{e}} \pm 0.01$ \\
\hline SEMIA 587 & $7.05^{\mathrm{a}} \pm 0.4$ & $0.92^{\mathrm{c}} \pm 0.1$ & $7.85^{\mathrm{d}} \pm 0.17$ & $5.99^{c} \pm 0.06$ \\
\hline SEMIA 5019 & $4.05^{\mathrm{c}} \pm 0.6$ & $0.93^{\mathrm{c}} \pm 0.1$ & $66.61^{\mathrm{a}} \pm 161$ & $4.36^{\mathrm{d}} \pm 0.01$ \\
\hline
\end{tabular}

Units: ${ }^{(1)} \mathrm{nM} \mathrm{NO}_{2}^{-}$produced. $\mathrm{h}^{-1}$. mg protein ${ }^{-1} ;{ }^{(2)} \mathrm{nM} \mathrm{NO}_{2}{ }^{-}$consumed. $\mathrm{h}^{-1}$. mg protein ${ }^{-1},{ }^{(3)} \mathrm{nM} \mathrm{NO}_{2}{ }^{-}$consumed. $\mathrm{h}^{-1}$. mg protein ${ }^{-1} ;{ }^{(4)} \mathrm{nM} \mathrm{N} \mathrm{N}_{2} \mathrm{O} \cdot \mathrm{h}^{-}$ ${ }^{1} . \mathrm{mg} \mathrm{protein}^{-1}$.

${ }^{(*)}$ B. diazoefficiens USDA 110 and CPAC 7; B. japonicum E109 and CPAC 15

${ }^{(* *)}$ B. elkanii SEMIA 587 and 5019

This article is protected by copyright. All rights reserved. 
Table 2

\begin{tabular}{ccc}
\hline Strain & NO production $^{(1)}$ & $\mathrm{N}_{2} \mathrm{O}$ production $^{(2)}$ \\
\hline USDA 110 & $70^{\mathrm{d}} \pm 5.02$ & $83^{\mathrm{e}} \pm 6.9$ \\
E109 & $148^{\mathrm{c}} \pm 9.5$ & $1528^{\mathrm{b}} \pm 131$ \\
CPAC 15 & $114^{\mathrm{c}} \pm 5.4$ & $628^{\mathrm{d}} \pm 15$ \\
CPAC 7 & $298^{\mathrm{c}} \pm 12.1$ & $91^{\mathrm{e}} \pm 5.2$ \\
SEMIA 587 & $76^{\mathrm{d}} \pm 4.3$ & $687^{\mathrm{d}} \pm 17.3$ \\
SEMIA 5019 & $447^{\mathrm{b}} \pm 16.12$ & $2174^{\mathrm{a}} \pm 165$ \\
GRC 131 & $787^{\mathrm{a}} \pm 69.2$ & $\mathrm{nd}$ \\
GRZ 3035 & nd & $1002^{\mathrm{c}} \pm 85.4$
\end{tabular}

nd: not determined

Units: ${ }^{(1)}$ relative fluorescence intensity units (RFIU); ${ }^{(2)} \mathrm{nM} \mathrm{N}_{2} \mathrm{O} \mathrm{h}^{-1} \cdot \mathrm{g}$ nodule fresh weight ${ }^{-1}$

This article is protected by copyright. All rights reserved. 
Table 3.

\begin{tabular}{|c|c|c|c|c|c|c|c|c|}
\hline \multirow[b]{2}{*}{ Strain } & \multicolumn{4}{|c|}{ Denitrification genes $^{(1)}$} & \multirow[b]{2}{*}{ Cited in } & \multicolumn{2}{|c|}{ NO Production ${ }^{(2)}$} & \multirow[b]{2}{*}{ Cited in } \\
\hline & napA & nirK & nor $\mathrm{C}$ & nos Z & & $\begin{array}{c}\text { free } \\
\text { living }\end{array}$ & Nodules & \\
\hline B. diazoefficiens USDA 110 & + & + & + & + & Bedmar et al. (2005) & Low & Low & Meakin et al. (2006) \\
\hline B. diazoefficiens CPAC7 & + & + & + & + & This study & Low & Low & This study \\
\hline B. japonicum E109 & + & + & + & - & This study & High & High & This study \\
\hline B. japonicum CPAC15 & + & + & + & - & This study & High & High & This study \\
\hline B. elkanii SEMIA $5019^{(3)}$ & - & - & - & - & This study & Medium & High & This study \\
\hline B. elkanii SEMIA $587^{(3)}$ & - & - & - & - & This study & Medium & Medium & This study \\
\hline
\end{tabular}

References: (+) Presence; (-) Absence

${ }^{(1)}$ in silico and in vitro analysis

${ }^{(2)} \mathrm{N}_{2} \mathrm{O}$ levels in comparison with reference strain (USDA 110)

${ }^{(3)}$ Genome sequence is not complete for SEMIA 587 or not available for SEMIA 5019

This article is protected by copyright. All rights reserved. 
Figure 1

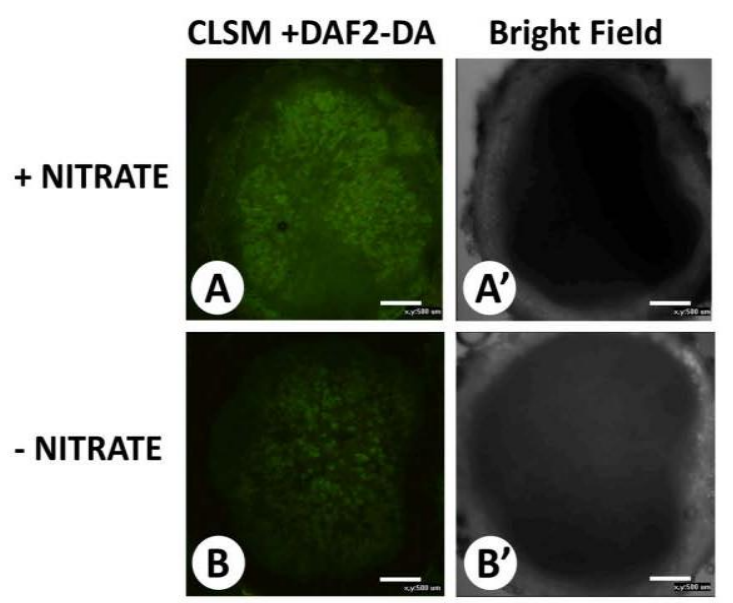

This article is protected by copyright. All rights reserved. 
Figure 2

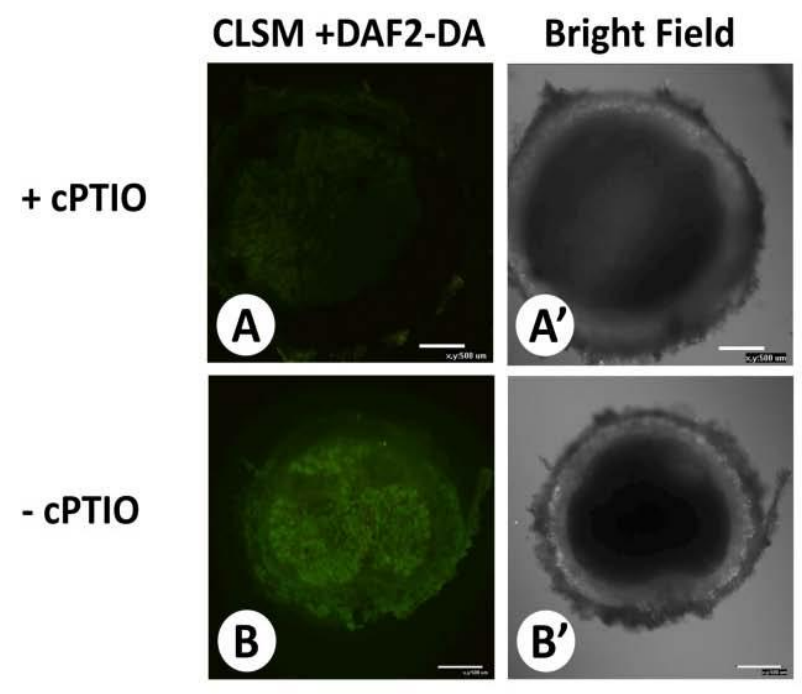

This article is protected by copyright. All rights reserved. 
Figure 3

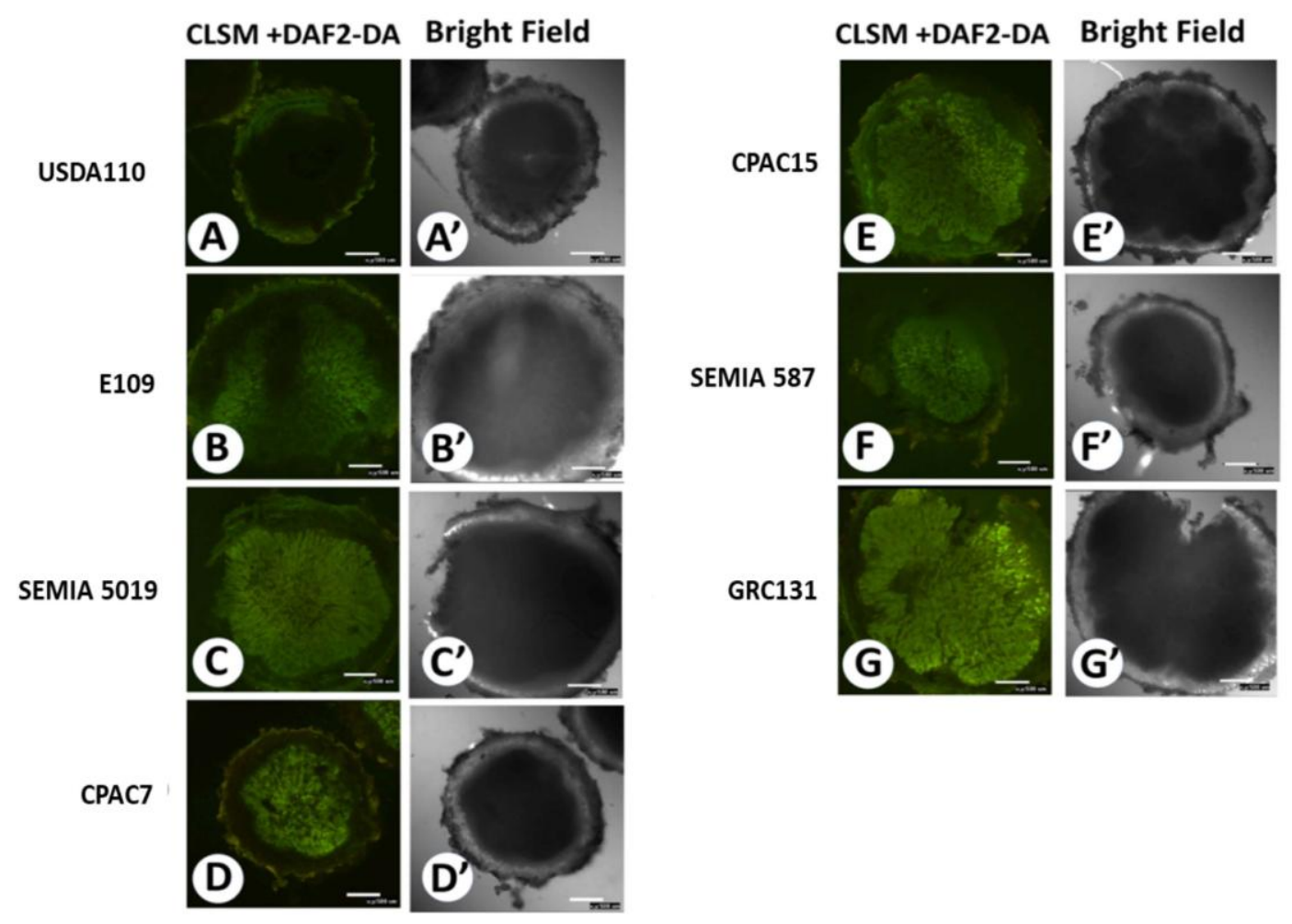

This article is protected by copyright. All rights reserved. 